\title{
PENGARUH PENDIDIKAN DAN PELATIHAN TERHADAP PENINGKATAN KINERJA PEGAWAI PADA DINAS PENDIDIKAN KOTA PAREPARE
}

\begin{abstract}
Ansir Launtu *)
Abstract : This Article was based on the research findings that attempted to describe the influence of education and training towards the improvement of the employee's work capability at Parepare City Department Of Education. There were two types of data that had been used in this study, i.e quantitative and qualitative. The data analysis was done through descriptive and comparative methods. The findings indicated that education and training had greater influence towards the employee's work capability at Parepare City Department Of Education, so that a greater number of education and training programs had beeb conducted. It was concluded that education and training programs for employee were very contributive for their work capability.
\end{abstract}

Keywords : education, training, work capability

\section{PENDAHULUAN}

Dewasa ini, pengembangan sumber daya manusia sebagai tujuan dan arah pem-bangunan nasional sudah seharusnya men-dapat perhatian yang tinggi. Keberhasilan upaya pengembangan sumber daya manusia yang berkualitas dan dengan pembangunan sektor ekonomi yang saling terkait dapat dikatakan sebagai indikator utama pem-bangunan nasional secara menyeluruh. Salah satu sektor penting yang terkait dengan upaya pengembangan sumber daya manusia dan pembangunan ekonomi ter-sebut adalah pembangunan sektor ketenaga kerjaan. Tenaga kerja yang berkualitas memiliki karakteristik keterangan bekerja, wawasan pengetahuan yang luas, pro-fesional, produktif dan memiliki etos kerja tinggi, sehingga mampu memberikan kontribusi yang berkualitas dan ber-kuantitas memadai terhadap pelayanan kebutuhan masyarakat dalam berbagai dimensi kehidupan.

Penyiapan tenaga kerja dan pembinaannya merupakan kebutuhan dan sekaligus sebagai keharusan. Penyiapan tenaga kerja yang memenuhi permintaan dan tuntunan lapangan dilakukan melalui pendidikan formal dalam berbagai jalur dan jenjang serta satuan pendidikan. Pembinaan tenaga kerja juga dilakukan melalui pembinaan secara langsung dengan program pelatihan. Dengan program pelatihan yang efisien dan efektif, maka kemampuan yang diperoleh melalui pendidikan formal dapat diperkaya dan terkait erat dan serasi dengan tuntutan lapangan kerja, yang terus meningkat. Dengan demikian, bukan hanya terjalin keterkaitan dengan lapangan, tetapi juga yang mengikuti perkembangan masyarakat dan perkembangan ilmu pengetahuan dan teknologi. Hal ini menggambarkan bahwa pelatihan saling terkait dengan pendidikan formal, pembinaan tenaga kerja dan kemajuan sesuai dengan lajunya pem-bangunan nasional.

Balai-balai latihan (DIKLAT) telah melaksanakan programnya sesuai dengan permintaan lembaga/instansi bersangkutan. Setiap lembaga DIKLAT masing-masing beroperasi dengan programnya sendiri-sendiri dan dikelola menurut seni dan versinya sendiri. Para pengusaha, pimpinan, instansional, 
pimpinan bagian personalia, para pelatih, tenaga pengembang (kuriku-lum dan teknologi pendidikan) serta semua unsur di bidang pembinaan memberikan perhatian yang besar terhadap masalah pen-didikan dan pelatihan tenaga kerja diling-kungannya masing-masing. Bahkan pihak Dinas Pendidikan Kota Parepare di bawah kepemimpinan Drs. H. Mustafa Mappangara tidak mengingkari bahwa pelaksanaan dan pelatihan mempunyai pengaruh yang besar manfaatnya dalam rangka meningkatkan kinerja pegawai di instansi pendidikan.

Pendidikan dan pelatihan dalam suatu organisasi sebagai salah satu upaya untuk pengembangan sumber daya manusia merupakan suatu siklus yang harus di-lakukan secara berkesinambungan. Dengan demikian, kemampuan sumber daya manusia dalam suatu organisasi harus ditingkatkan sejalan dengan kemajuan dan perkembangan organisasi

Menurut Abdurrahmat Fathoni (2006: 96), pendidikan dan pelatihan adalah salah satu pembinaan terhadap tenaga kerja di samping adanya upaya yang lain. Pen-didikan merupakan proses belajar mengajar dalam rangka meningkatkan kemampuan sumber daya manusia dalam melaksanakan tugasnya sedangkan yang dimaksud dengan pelatihan adalah upaya untuk mentransfer keterampilan dan pengetahuan kepada para peserta pelatihan sedemikian rupa sehingga para peserta menerima dan melakukan pelatihan pada saat melaksanakan pekerjaan.

Sedangkan menurut instruksi Presiden Republik Indonesia, Nomor 15 tanggal 13 September 1974, pendidikan adalah segala usaha untuk membina kepribadian dan mengembangkan kemampuan manusia Indonesia jasmaniah dan rohaniah, yang berlangsung seumur hidup, baik di dalam maupun di luar sekolah, dalam rang-ka pembangunan persatuan Indonesia dan masyarakat adil dan makmur berdasarkan Pancasila. Latihan adalah bagian pendidi-kan yang menyangkut proses belajar untuk memperoleh dan meningkatkan keterampilan di luar sistem pendidikan yang berlaku, dalam waktu yang relatif singkat dan dengan metode yang lebih mengutamakan praktek daripada teori.

Dari uraian di atas, jelaslah bahwa pendidikan dan pelatihan dengan berbagai programnya mempunyai peranan penting dalam proses memperoleh dan meningkat-kan kualitas kemampuan profesional indi-vidu. Melalui pendidikan dan pelatihan, seseorang dipersiapkan untuk memiliki bekal agar siap tahu, mengenal dan mengembangkan metode berpikir secara sistematik agar dapat memecahkan masalah yang akan dihadapi dalam kehidupan dikemudian hari. Hal tersebut nantinya akan nampak pada kinerjanya, yang pada akhirnya akan menjamin prestasi kerja yang semakin meningkat.

Tujuan pendidikan dan pelatihan pada hakekatnya adalah suatu pernyataan tentang kehendak terjadinya perubahan suatu proses. Dalam pencapaian harapan, tujuan, dan hasil harus dapat diamati dan diukur, spesifik, dengan lamanya waktu pendidikan dan pelatihan serta upaya pencapaiannya dapat dikelola dengan baik. Pendidikan dan pelatihan pegawai ber-tujuan dan bermanfaat bagi perusahaan, pegawai, konsumen atau masyarakat yang mengkomsumsi barang/jasa yang dihasil-kan perusahaan.

Menurut Mutiara S. Pangabean (2004 : 45) metode pelatihan dan pengem-bangan pada dasarnya dikelompokkan ke dalam dua kelompok yaitu :

a. On the job training (latihan sambil bekerja) 
Meliputi semua upaya melatih pegawai untuk mempelajari suatu pekerjaan sambil mengerjakannya di tempatkerja yang sesungguhnya. On the job training meliputi: program magang, rotasi pekerjaan, under study atau coaching.

\section{b. Off the job training}

Pelatihan dan pengembangan dilak-sanakan pada lokasi terpisah dengan tempat kerja. Program ini memberikan individu dengan keahlian dan pengetahuan mereka yang dibutuhkan untuk melaksanakan pekerjaan pada waktu terpisah dari waktu kerja regular mereka.

\section{METODE PENELITIAN}

Untuk mengumpulkan data/informasi yang diperlukan dalam kaitannya dengan pembahasan penulisan ini, maka dilakukan pengumpulan data melalui teknik Penelitian sebagai berikut :

1. Observasi, yaitu melakukan pengamat-an secara langsung pada obyek pene-litian dan pengumpulan data yang diperlukan.

2. Wawancara yaitu melakukan tanya jawab dengan pimpinan dan pegawai untuk mendapatkan data yang diperlukan.

Jenis data yang digunakan untuk menganalisis hasil penelitian adalah sebagai berikut :

1. Data kuantitatif, yaitu data dalam bentuk angka-angka yang diperoleh dari obyek penelitian.

2. Data kualitatif, yaitu data dalam bentuk informasi baik secara lisan maupun tulisan yang diperoleh dari obyek penelitian.

Metode analisis yang digunakan dalam penulisan ini adalah sebagai berikut :

1. Analisis deskriptif, yaitu analisis yang menjelaskan/membahas tentang pen-didikan dan pelatihan yang dilakukan oleh pihak Dinas Pendidikan Kota Parepare.

2. Analisis komparatif, yaitu analisis yang membandingkan sebelum mengikuti pendidikan dan pelatihan dengan sesudah mengikuti pendidikan dan pelatihan oleh pegawai Dinas Pendidikan Kota Parepare.

\section{HASIL PENELITIAN DAN PEMBAHASAN}

\section{Pengaruh Pendidikan dan Pelatihan Pegawai}

Kegiatan Diklat diawali dengan pe-netapan peserta secara efektif dan merupa-kan penugasan instansi yang bersangkutan berserta tim seleksi perserta Diklat Instansi (TSDDI) dan juga ditetapkan oleh pejabat pembina kepegawaian peserta yang akan diikutsertakan dalam diklat dengan persyaratan sebagai berikut:

1. Memiliki potensi untuk berkembang

2. Memiliki motivasi tinggi untuk pengembangan diri

3. Mampu menjaga reputasi dan kreadibilitas sebagai PNS

4. Memiliki dedikasi dan loyalitas terhadap tugas dan organisasi.

5. Berprestasi baik dalam melaksanakan tugas.

Peserta yang akan diikut sertakan tidak memilih apakah pegawai lama atau baru, yang penting pegawai tersebut sudah bersedia dan sudah memenuhi kriteria dalam mengembangkan karier dengan ikut pendidikan dan palatihan sebagai dasar untuk meningkatkan kinerja. Namun pada pegawai yang belum sempat di ikutsertakan dalam program pendidikan dan pelatihan tersebut, harus secara bertahap setiap pegawai pasti diberi kesempatan untuk mendapat giliran untuk mengikuti pendidi-kan dan pelatihan. 
Adapun jenis pendidikan dan pelatihan pegawai pada Dinas Pendidikan Kota Parepare antara lain :

1. Diklat Model Pembelajaran

2. Diklat KTSP

3. Diklat Prajabatan Golongan II

4. Diklat Ujian Dinas Tingkat I

5. Diklat Ujian Penyesuaian Kenaikan Pangkat Tingkat II

6. Diklat Ujian Penyesuaian Kenaikan Pangkat V

7. Diklat Ujian Penyesuaian Kenaikan Pangkat Tingkat VI

8. Diklat Kememimpinan Tingkat IV

9. Diklat Kepemimpinan Tingkat III

\section{Peningkatan Kinerja Pegawai}

Menilai pegawai dari tingkat kiner-ja sebelum dan sesudah diklat merupakan alat manajemen yang baik untuk mengukur hasil usaha mereka. Dengan adanya pemikiran tersebut maka Dinas Pendidikan Kota Parepare menjadi penilaian prestasi kerja pada pegawai sebagai suatu usaha untuk terus menerus melihat perkembangan pegawai yang dimilikinya dalam melaksanakan tugas-tugasnya Dinas Pendidikan Kota Parepare sebaiknya melakukan tindakan-tindakan penilaian ter-hadap para pegawainya. Dengan demikian Dinas Pendidikan Kota Parepare akan dapat mengetahui kekurangankekurangan serta kelemahan-kelemahan yang terjadi pada setiap pegawai baik sebelum dan sesudah diklat penilaian yang dilakukan oleh Dinas Pendidikan Kota Parepare ini dapat diambil dari kegiatan-kegiatan sehari-hari, juga ada penilaian yang dilakukan secara berkala yakni setahun sekali, mengingat pentingnya penilaian berbagai proses melalui evaluasi atau penilaian kinerja pegawai sebelum dan sesudah Diklat.

Tujuan diadakannya penilaian oleh Dinas Pendidikan Kota Parepare adalah digunakan untuk penilaian dalam mendorong dan mengem-bangkan pegawai, juga untuk dapat mengetahui apa dan bagaimana pegawai tersebut bekerja. Dengan adanya penilaian mau tidak mau setiap atasan akan memperhatikan para bawahannya.

Sistem penilaian prestasi yang dilakukan oleh Dinas Pendidikan Kota Parepare adalah sistem skala grafik, dimana terdapat daftar penilaian tingkat kinerja pegawai yang terdiri dari lima bagian yaitu :

1. Data perorangan

2. Tingkat prestasi

3. Keterangan lain-lain

4. Kesimpulan penilai

5. Tanda tangan penilai

Dalam penilaian baik secara khusus maupun umum tersedia tempat untuk mencatat nama pegawai, golongan/ruang/ angka skala dan nomor induk pegawai dan jabatan. Tingkat prestasi dalam bagian ini yang akan dinilai adalah kecakapan, watak dan tingkah laku serta loyalitas baik kepada negara maupun instansi. Keterangan lain-lain akan kita peroleh tentang halhal yang dipertimbangkan dalam menilai pegawai.

Kesimpulan penilai, berisi tentang hasil-hasil yang diperolehnya selama mela-kukan penilaian. Tanda tangan penilai me-rupakan bagian terakhir dan akan memuat tentang nama dan jabatan penilai, disam-ping itu juga dituntut diketahui oleh atasan penilai.

Dalam pemberian nilai kepada pegawai harus sesuai dengan predikat yang dicapai baik sebelum dan sesudah Diklat oleh pegawai, maka penilaian untuk mem-berikan tanda tangan menggambarkan ciri-ciri atau karakteristik yang dimiliki oleh pegawai.

Berikut ini contoh format penilaian kinerja pegawai sebelum dan sesudah Diklat pada Dinas Pendidikan Kota Parepare. 
Skor Penilaian Tingkat Kinerja Pegawai Sebelum dan sesudah diklat pada Dinas Pendidikan Kota Parepare

\begin{tabular}{|c|c|c|c|c|c|c|c|c|c|}
\hline \multirow{2}{*}{ No } & \multirow{2}{*}{ Materi Penilaian } & \multicolumn{4}{|c|}{ Skor Penilaian Sebelum Diklat } & \multicolumn{4}{|c|}{ Skor Penilaian Sesudah Diklat } \\
\hline & & $40-55$ & $56-70$ & $71-80$ & $81-100$ & $40-55$ & $56-70$ & $71-80$ & $81-100$ \\
\hline 1 & Sikap & & \multirow{4}{*}{65} & 80 & & & & \multirow{7}{*}{79} & 98 \\
\hline 2 & Pengetahuan & & & 75 & & & & & 90 \\
\hline 3 & Keterampilan & & & & & & & & 92 \\
\hline 4 & Kemampuan bekerja & & & 75 & & & & & 87 \\
\hline 5 & Ketepatan waktu & & \multirow[t]{3}{*}{65} & & & & & & \\
\hline 6 & Kepatuhan pada atasan & & & 80 & & & & & 93 \\
\hline \multirow[t]{2}{*}{7} & Kerjasama & & & 80 & & & & & 88 \\
\hline & Catatan Kepala Seksi & & & & & \multicolumn{4}{|c|}{ Prestasi Kerja Meningkat } \\
\hline
\end{tabular}

Sumber : Dinas Pendidikan Kota Parepare 2013

Angka Penilaian : $81-100$ baik sekali

$$
\begin{array}{ll}
71-80 & \text { baik } \\
56-70 & \text { sedang } \\
40-55 & \text { kurang }
\end{array}
$$

Berdasarkan tabel diatas dapat dijelaskan bahwa skor penilaian sikap sebelum diklat dan sesudah diklat 98 skor penilaian pengetahuan sebelum diklat 75 dan sesudah diklat 90 skor penilaian keterampilan sebelum diklat 65 dan sesudah diklat 92 skor penilaian kemampuan bekerja sebelum diklat 75 dan sesudah diklat 65 dan sesudah diklat 79. Skor penilaian kepatuhan pada perintah atasan sebelum diklat 80 dan sesudah diklat 80 dan sesudah diklat 88 . Hal ini berarti perbedaan tingkat kinerja pegawai sebelum dan sesudah diklat sangat dirasakan oleh pihak Dinas Pendidikan Kota Parepare.

Untuk melihat sejauh mana kegiatan diklat dalam meningkatkan kinerja yang telah diterapkan oleh Dinas Pendidikan Kota Parepare, maka berikut ini penulis akan menguraikan mengenai perbandingan sebelum dan sesudah diklat terhadap kinerja pegawai.

1. Sebelum pegawai diikutsertakan dalam kegiatan pengembangan dalam hal ini pendidikan dan pelatihan, para pegawai dalam menyelesaikan tugas-tugasnya masih terdapat kesalahan-kesalahan, dan masih belum mampu menyelesaikan tugas-tugas yang diberikan secara efektif dan efisien, karena disebabkan ketidak sesuaikan jenis pekerjaan yang diberikan dengan pengetahuan, kemampuan dan keterampilan pegawai serta sarana dan prasarana kurang menunjang.

2. Setelah diadakan pendidikan dan pelatihan pegawai, tingkat kinerja pegawai meningkat. Pada kenyataan yang terlihat dan dirasakan setelah adanya pendidikan dan pelatihan, secara garis besar dapat dikemukakan sebagai berikut :

a. Para pegawai meningkatkan disiplin kerja yang cukup tinggi, di mana para pegawai dapat menggunakan waktu secara tepat dan semakin produktif dalam tugas dan pekerjaannya.

b. Loyalitas pegawai dalam memelihara dan mengembangkan kondisi dan suasana kerja nyaman dan sehat dalam lingkungan kerjanya.

c. Dampak diklat pada pegawai betulbetul memperhatikan kedisip-linan waktu bekerja, dan kesopanan.

d. Kegairahan bekerja setelah petunjuk dan arahan-arahan terhadap peningkatan prestasi.

e. Peningkatan prestasi pegawai membuat suasana kerja tentram dalam membuat kerjasama di antara satu dengan yang lainnya. 


\section{PENUTUP}

\section{Kesimpulan}

Dari hasil pembahasan tentang pengaruh pendidikan dan pelatihan terhadap peningkatan kinerja pegawai dan Dinas Pendidikan Kota Parepare, maka dapat ditarik kesimpulan sebagai berikut :

Pendidikan dan pelatihan adalah proses pembelajaran secara teori dan praktik kepada pegawai agar mampu mening-katkan kemampuan, pengetahuan dan keterampilan serta merubah sikap dalam melaksanakan tugas dan tang-gung jawab yang diberikan oleh instansi.

Pendidikan dan pelatihan yang dilakukan Dinas Pendidikan Kota Parepare kepada pegawai-nya sangat berpengaruh dalam upaya peningkatan kinerja pegawai dalam menghadapi tanggung jawab dari instansi

Bila dibandingkan prestasi kerja pegawai sebelum mengikuti Diklat cukup menggembirakan karena memberikan kontribusi kinerja yang sangat baik. Hal ini menunjukkan bahwa Dinas Pendidikan Kota Parepare sangat memperhatikan pendidikan dan pelatihan bagi para pegawainya.

\section{Saran}

Sebagaimana telah dibahas bahwa pendidikan dan pelatihan sangat ber-peran dalam upaya peningkatan kinerja pegawai yang dikehendaki oleh Dinas Pendidikan Kota Parepare sehingga pelaksanaan pendidikan dan pelatihan harus dilakukan secara rutin dan dapat ditingkatkan.

Pelaksanaan pendidikan dan pelatihan harus selalu berdasarkan prinsip yaitu harus berkaitan dengan analisa jabatan yang berkesinambungan.

\section{DAFTAR PUSTAKA}

Hasibuan, Malayu.S.P. 2006 . Manajemen Sumber Daya Manusia ,Edisi Revisi. Bumi Aksara : Jakarta.
Hamalik, Umar. 2001. Manajemen Sumber Daya Manusia. Manajemen Pelatihan ketenagakerjaan, Edisi I. Bumi Aksara : Jakarta.

Pangabean, M.S. 2002. Manajemen Sumber Daya Manusia.Ghaira Indonesia : Bogor.

Sinungan, M. 2003. Produktifitas Apa dan Bagaimana Sumber Daya Manusia.Refika Aditama : Bandung.

Manullang, M. 2001. Manajemen Personalia, Edisi 3. Gadjah Mada University Press. Indonesia : Jakarta.

Mangkuprawira, Syafri, Tb. 2004. Manajemen Sumber Daya Manusia Strategik. Ghaira Indonesia : Jakarta.

Sedarmayanti. 2001. Sumber Daya Manusia dan Produktifitas Kerja. Mandar Maju : Bandung.

Notoatmodjo, $\quad$ Soekidjo. 1998. Pengembangan Sumber Daya Manusia. Rineka Cipta : Jakarta.

Fathoni, Abdurrahmat. 2006. Manajemen Sumber Daya Manusia. Rineka Cipta : Jakarta.

Hani Handoko T. 1999. Manajemen Personalia dan Sumber Daya Manusia, Edisi I. Liberty : Yogyakarta.

Ranupandjojo Heidjrachman. 1998. Manajemen Personalia. Cetakan Ketiga. Fakultas Ekonomi Universitas, Gadjah Mada. : Yogyakarta

*) Penulis adalah Dosen Tetap Yayasan STIEM Bongaya Makassar 